\title{
Aptamers: Update to Lateral Flow Immunoassays
}

\author{
Gurdyal Singh* and Vikas Pahal \\ ${ }^{1}$ Department of Microbiology, Dolphin $(P G)$ College of Life Sciences, Punjabi University, India
}

Submission: September 20, 2017; Published: October 20, 2017

*Corresponding author: Gurdyal Singh, Department of Microbiology, Dolphin (PG) College of Life Sciences (Punjabi University), Fatehgarh Sahib, Punjab, India, Email: gsjabal@gmail.com

\begin{abstract}
A key driver for treatment of a disease is the time to obtain the test result. Lateral flow immunoassays are multifaceted and available for a broad range of analytes from blood proteins, mycotoxins, viral pathogens or bacterial toxins. The other key advantage of these rapid tests as compared to other immunoassays is the simplicity of the test with requirement of little sample or reagent preparation. Lateral flow assay requires assembly of a number of variants such as formats, biorecognition molecules, labels, detection systems and applications. This manuscript provides a brief overview of use of aptamers in lateral flow assay without using whole antigens or antibodies for the targets. Due to a number of important potential performance advantages, aptamers are receiving increasing attention in lateral flow applications. The identification of specific nucleic acids (aptamers) which bind to a wide range of target molecules with high affinity and specificity is done by in vitro selection of combinatorial libraries of RNA or DNA. These are used as new biological recognition molecules in lateral flow immunoassays assuring progress for fast and easy detection of antigens/antibodies.
\end{abstract}

Keywords: Lateral flow immunoassay; Biorecognition; Aptamer; Nucleic acid

\section{Introduction}

Lateral flow assay (LFA) based Point of Care (POC) devices are among very rapidly growing strategies for qualitative and quantitative analysis. One step rapid analysis, very low operational cost, no instrumentation, less or no interferences due to chromatographic separation, high specificity \& sensitivity, and portability of the device are unique advantages related to LFA [1]. It is performed over a strip, different parts of which are assembled on a plastic (PVC) backing. These strips include sample pad, conjugate pad, nitrocellulose membrane and adsorption pad [2]. Nitrocellulose membrane is further coated with specific biorecognition molecules for test and control line. Pre-immobilized reagents at conjugate pad and nitrocellulose membrane of the strip become active upon lateral flow of liquid sample. In ELISA, immunobead assay, western blotting, microarrays and biosensors, proteins are detected mostly by specific antibodies. But, aptamers are equal to monoclonal antibodies concerning their binding affinities and their other decisive advantages [3].

\section{Aptamers in LFA}

There have been attempted many efforts for lateral flow immunoassays to improve the sensitivity, reproducibility, quantification, and multiplexing capability. Both DNA and RNA aptamers show robust binding affinities for various targets [4-6]. These are very small in size (30 to 100 nucleotides) in comparison to other biorecognition molecules like antibodies or enzymes which allows competent immobilization at high density. Therefore, use of aptamers over antibodies in miniaturization and integration of lateral flow immunoassays can be accomplished more easily.

Aptamers are able to recognize a distinct epitope of a target molecule and can distinguish between chiral molecules $[7,8]$. These can be engineered completely in a test tube, can be readily produced by chemical synthesis and possess desirable storage properties. For any desired target, even non-immunogenic or toxic proteins, aptamers can be selected virtually, because they are produced in vitro by an evolutionary method called SELEX (systematic evolution of ligands by exponential enrichment) process $[9,10]$. The big variety of DNA/RNA library and the amplification steps of target-binding oligonucleotides during the selection process considerably facilitate the selection of ligands with highest affinity [11]. To direct the selection to aptamers with desired features, the SELEX conditions can be further modified. Also, it has been proved that one aptamer could be split into two pieces, which could simultaneously bind to the same target such as thrombin, ATP, theophylline, 17 beta-estradiol, and cocaine [12-19]. An aptamer based lateral flow strip with competitive format has been developed for on-site rapid detection of ochratoxin A (OTA) in Astragalusmembranaceus [20]. 


\section{Discussion}

Currently many diagnostic tests rely on antibodies, which are used as biorecognition molecules to detect a targeted molecule. The common pregnancy test, for example, detects pregnancy when an antibody indicator binds to a glycoprotein (hCG), found in urine [21]. Aptamers could be described as synthetic antibodies, single-stranded DNA or RNA molecules that can bind to pre-selected targets. They are regarded as having many advantages over antibodies. Because of their exceptionally high stability, selectivity and sensitivity, aptamer based lateral flow immunoassys have the potential to overcome the lacking functional and storage stability of most lateral flow tests.

\section{Conclusion}

The use of aptamers as new biological receptors can accelerate the development of lateral flow immunoassays of practical relevance. The more aptamers for proteins will be developed and characterized, the more aptamer based lateral flow immunoassays will be developed in the future.

\section{References}

1. Li Z, Wang Y, Wang J, Tang Z, Pounds JG, et al. (2010) Rapid and sensitive detection of protein biomarker using a portable fluorescence biosensor based on quantum dots and a lateral flow test strip. Anal Chem 82(16): 7008-7014.

2. Manta P, Agarwal S, Singh G, Bhamrah SS (2015) Formulation, development and sensitivity, specificity comparison of gold, platinum and silver nano particle based HIV $1 / 2$ and hCG IVD rapid test kit (Immune chromatoghraphic test device). World Journal of Pharmacy and Pharmaceutical Sciences 4(05): 1870-1905.

3. Strehlitz B, Nikolaus N, Stoltenburg R (2008) Protein detection with aptamer biosensors. Sensors (Basel) 8(7): 4296-4307.

4. Neves MA, Reinstein O, Saad M, Johnson PE (2010) Defining the secondary structural requirements of a cocaine-binding aptamer by a thermodynamic and mutation study. Biophys Chem 153(1): 9-16.

5. Baugh C, Grate D, Wilson C (2000) 2.8 angstrom crystal structure of the malachite green aptamer. J Mol Biol 301(1): 117-128.

6. Dieckmann T, Fujikawa E, Xhao X, Szostak J, Feigon J (1995) Structural investigations of RNA and DNA aptamers in solution. Journal of Cellular Biochemistry 59: 56.

7. Jenison RD, Gill SC, Pardi A, Polisky B (1994) High-resolution molecular discrimination by RNA. Science 263(5152): 1425-1429.
8. Michaud M, Jourdan E, Villet A, Ravel A, Grosset C, et al. (2003) A DNA aptamer as a new target-specific chiral selector for HPLC. J Am Chem Soc 125(28): 8672-8679.

9. Ellington AD, Szostak JW (1990) In vitro selection of RNA molecules that bind specific ligands. Nature 346(6287): 818-822.

10. Tuerk C, Gold L (1990) Systematic evolution of ligands by exponential enrichment: RNA ligands to bacteriophage T4 DNA polymerase. Science 249(4968): 505-510.

11. Stoltenburg R, Reinemann C, Strehlitz B (2007) SELEX-A (r) evolutionary method to generate high-affinity nucleic acid ligands. Biomol Eng 24(4): 381-403.

12. Bai YF, Feng, F, Zhao L, Chen ZZ, Wang HY, et al. (2014) A turn-on fluorescent aptasensor for adenosine detection based on split aptamers and graphene oxide. Analyst 139(8): 1843-1846.

13. Liu JC, Bai WH, Niu SC, Zhu C, Yang SM, et al. (2014) Highly sensitive colorimetric detection of $17 \beta$-estradiol using split DNA aptamers immobilized on unmodified gold nanoparticles. Sci Rep 19(4): 7571.

14. Cheng S, Zheng B, Wang MZ, Lam MHW, Ge XW (2013) Double functionalized gold nanoparticles with split aptamer for the detection of adenosine triphosphate. Talanta 115: 506-511.

15. Chen JH, Zeng LW (2013) Enzyme-amplified electronic logic gates based on split/intact aptamers. Biosens Bioelectron 42: 93-99.

16. He X, Li Z, Jia X, Wang K, Yin J (2013) A highly selective sandwichtype FRET assay for ATP detection based on silica coated photon upconverting nanoparticles and split aptamer. Talanta 111: 105-110.

17. Chen J, Fang Z, Lie P, Zeng L (2012) Computational lateral flow biosensor for proteins and small molecules: a new class of strip logic gates. Anal Chem 84(15): 6321-6325.

18. Wu CC, Yan L, Wang CM, Lin HX, Wang C, et al. (2010) A general excimer signaling approach for aptamer sensors. Biosens Bioelectron 25(10): 2232-2237.

19. Zuo X, Xiao Y, Plaxco KW (2009) High specificity, electrochemical sandwich assays based on single aptamer sequences and suitable for the direct detection of small-molecule targets in blood and other complex matrices. J Am ChemSoc 131(20): 6944-6945.

20. Zhou W, Kong W, Dou X, Zhao M, Ouyang Z, et al. (2016) An aptamer based lateral flow strip for on-site rapid detection of ochratoxin $A$ in Astragalusmembranaceus. J Chromatogr B Analyt Technol Biomed Life Sci 1(1022): 102-108.

21. Gronowski AM (2004) Handbook of clinical laboratory testing during pregnancy. Current clinical pathology Totowa, Humana Press, New York, USA, p. 15
Your next submission with Juniper Publishers will reach you the below assets

- Quality Editorial service

- Swift Peer Review

- Reprints availability

- E-prints Service

- Manuscript Podcast for convenient understanding

- Global attainment for your research

- Manuscript accessibility in different formats

( Pdf, E-pub, Full Text, Audio)

- Unceasing customer service

Track the below URL for one-step submission

https://juniperpublishers.com/online-submission.php 